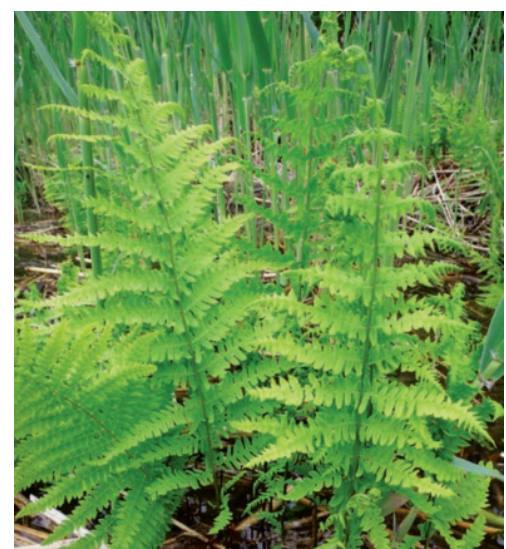

Perennial wetland fern, deciduous, underground with creeping rootstock. Soft, pale green 2-pinnate leaves arise singly, they are 30-100 cm high, stalks almost hairless. Spore cases rounded, close together.

\section{Distribution and ecology}

Euro-Siberian boreo-temperate element; widely naturalised outside its native range. Native in all CE countries. Typical of marshes, fens, mires, wet grasslands, pastures, wet woodlands, springs and tall-herb vegetation in mountains. Persistent spore bank.

\section{Anatomy of the petiole}

The lower part of the petiole has a diameter of $3 \mathrm{~mm}(1,2)$. Secondary growth is absent.

Two to four oval vascular bundles are surrounded by a thin-walled parenchymatic tissue $(3,4)$. Vascular bundles are composed of a xylem with angularly lignified thin-walled tracheids with a diameter up to $100 \mu \mathrm{m}$ and an unlignified, small parenchyma cells $(2,3)$. Tracheids have scalariform pits. The surrounding phloem consists of angular, unlignified sieve elements and companion cells. Vascular bundles are surrounded by a layer of living, unlignified, thin-walled parenchyma cells and an endodermis (4). Endodermis cell walls are brown stained and fairly thick-walled at its outer and inner part and extremely thin-walled laterally (4). Therefore, most vascular bundles do not resist the sectioning process (1). Cells of the peripheral part of the petiole are brown stained and thick-walled (5).
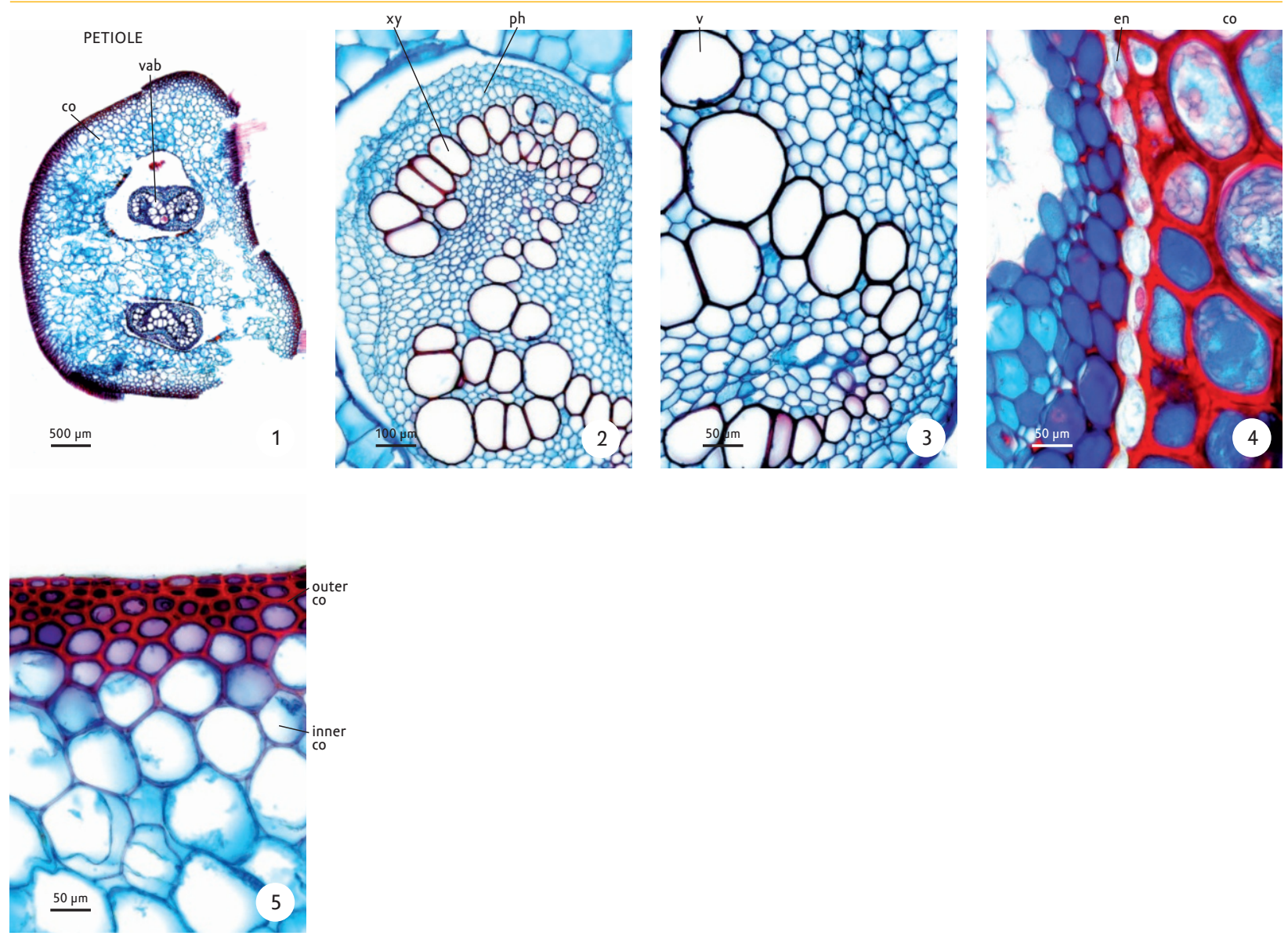